\title{
Two new species of Philometra (Nematoda: Philometridae) parasitic in the perciform fish Cynoscion nebulosus (Sciaenidae) in the estuaries of South Carolina, USA
}

\author{
František Moravec $^{1}$, Isaure de Buron ${ }^{2}$ and William A. Roumillat ${ }^{3}$ \\ ${ }^{1}$ Institute of Parasitology, Academy of Sciences of the Czech Republic, Branišovská 31, 37005 České Budějovice, Czech \\ Republic; \\ ${ }^{2}$ Department of Biology, College of Charleston, 58 Coming Street, Charleston, South Carolina 29401, USA; \\ ${ }^{3}$ Marine Resources Research Institute, South Carolina Department of Natural Resources, Charleston, South Carolina 29422, USA
}

Key words: parasitic nematode, Philometra, new species, estuarine fish, Cynoscion, South Carolina, USA, West Atlantic Ocean

\begin{abstract}
Two new nematode species of Philometra Costa, 1845, P. carolinensis $\mathrm{sp} . \mathrm{n}$. and P. cynoscionis $\mathrm{sp} . \mathrm{n}$., are described from the spotted seatrout, Cynoscion nebulosus (Cuvier) (Sciaenidae, Perciformes) in estuaries on the Atlantic coast of South Carolina, USA. Philometra carolinensis (males and gravid and subgravid females) parasitic in the host's ovary is most similar to P. lateolabracis (Yamaguti, 1935) in female morphology, but distinctly differs from it in possessing conspicuously short spicules (81-87 $\mu \mathrm{m}$ long) with heavily sclerotized distal parts, the gubernaculum bearing a reflected dorsal barb, and in the length ratio of the gubernaculum and spicules (1:1.23-1.42) in the male. Philometra cynoscionis (only gravid females) found subcutaneously in the host's tissue (lateral to the ascending process of the premaxilla and also posteromedial to the length of each maxilla) is characterized mainly by the presence of cephalic papillae arranged in two circles ( 8 large papillae in outer circle and 6 small papillae in inner circle), the absence of caudal projections, the body size (length of gravid female 20-33 mm) and the location in the host.
\end{abstract}

During recent investigations into the parasites of fishes in the estuarine systems on the Atlantic coast of South Carolina carried out by the research team of one of the authors (I. de Buron), the spotted seatrout $C y$ noscion nebulosus (Cuvier) was found to harbour philometrid nematodes located in the ovaries and in the subcutaneous tissue of the head (lateral to the ascending process of each premaxilla, and posteromedial to each maxilla). These proved to represent two previously undescribed species of the genus Philometra Costa, 1845, which are described herein.

Cynoscion nebulosus is an important food and sport fish (up to $1 \mathrm{~m}$ long and $7 \mathrm{~kg}$ weight) inhabiting estuaries of rivers and shallow coastal waters, distributed in the West Atlantic from New York to Florida and in the entire Gulf of Mexico (Froese and Pauly 2005).

\section{MATERIALS AND METHODS}

Spotted seatrout were collected using trammel netting during daytime ebbing tides primarily over mud and oyster shell substrates adjacent to the marsh $(<2 \mathrm{~m}$ depth). Fish were measured, placed on ice and transported to the laboratory for immediate dissection. Nematodes recovered were washed in physiological saline and then fixed in $70 \%$ ethanol or in $4 \%$ or $10 \%$ formaldehyde solution in physiological saline. Some specimens were fixed and stored in $95 \%$ ethanol for subsequent DNA examination. For light microscopy, specimens were cleared with glycerine. Drawings were made with the aid of a Zeiss drawing attachment. After examination, male specimens were mounted in glycerine-jelly as slides, female specimens were maintained in $70 \%$ ethanol in vials. Specimens used for scanning electron microscopy (SEM) were transferred to $4 \%$ formalin and then postfixed in $1 \%$ osmium tetroxide, dehydrated through a graded ethanol series, critical point dried and sputter-coated with gold; they were examined using a JSM-6300 scanning electron microscope at an accelerating voltage of $15 \mathrm{kV}$. All measurements are in micrometres unless otherwise stated. The names of fishes follow Nelson et al. (2004) and Froese and Pauly (2005)

\section{DESCRIPTIONS}

Philometra carolinensis sp. $\mathrm{n}$.

Figs. 1, 2

Male (4 specimens; measurements of holotype in parentheses): Body filiform, whitish, 1.59-1.85 (1.80) $\mathrm{mm}$ long, maximum width at middle 51-57 (51), slightly tapering towards both ends. Cuticle smooth. Cephalic end rounded. Mouth small, surrounded by indistinct cephalic papillae. Oesophagus 315-384 (381) long (19$21[21] \%$ of body length), without distinct anterior inflation; posterior part of muscular oesophagus provided with well-developed dorsal oesophageal gland with large cell nucleus in middle. Nerve ring, excretory pore and oesophageal cell nucleus 108-129 (111), 138-156 (156) and 219-309 (282), respectively, from anterior extremity. Posterior end of body blunt, with broad, Ushaped, lobular mound and with one pair of preanal and

Address for correspondence: F. Moravec, Institute of Parasitology, Academy of Sciences of the Czech Republic, Branišovská 31 , 37005 České Budějovice, Czech Republic. Phone: ++420 387775 432; Fax: ++420 385310 388; E-mail: moravec@paru.cas.cz 

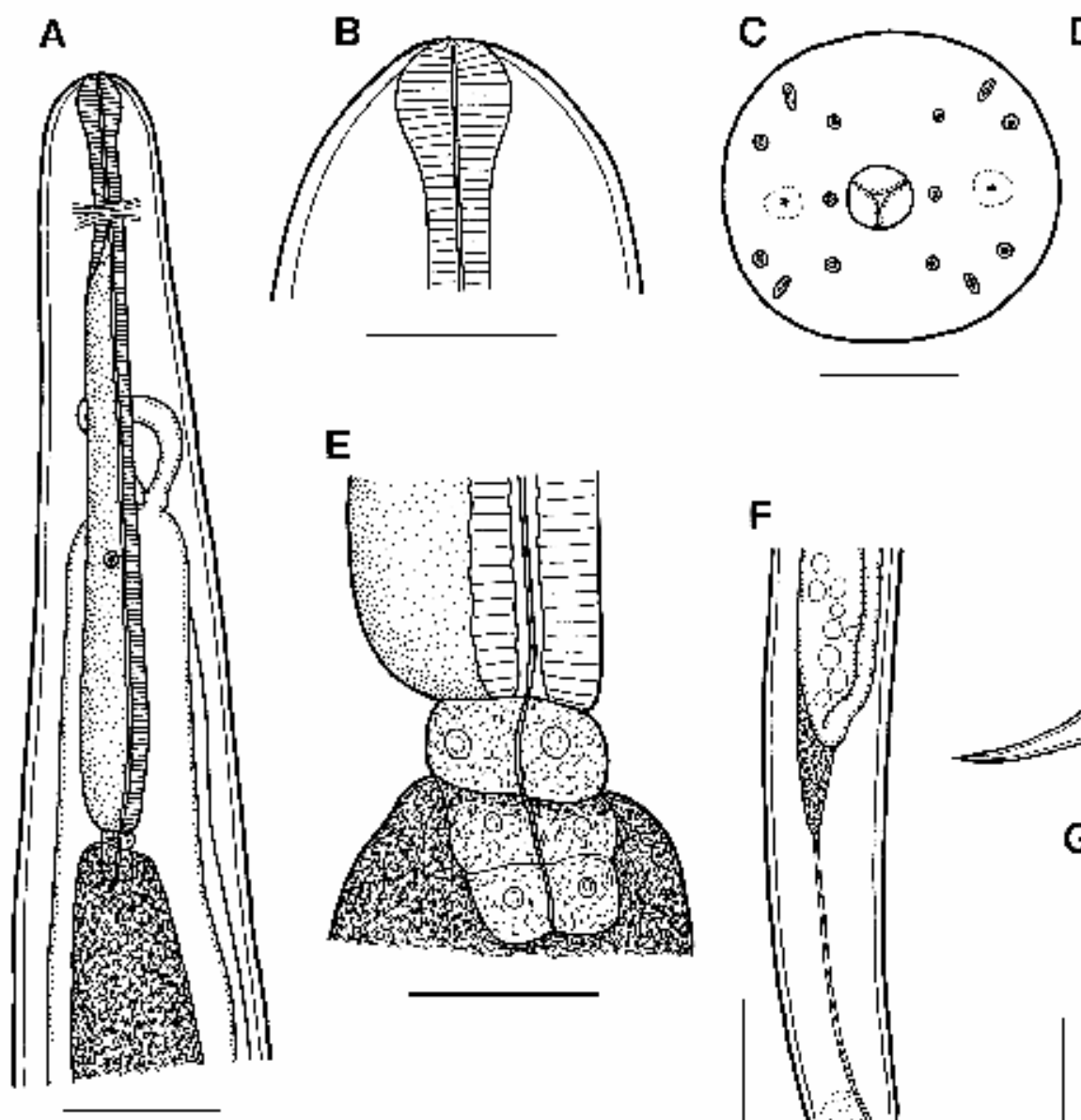

D

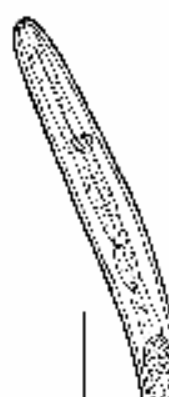

\section{E}
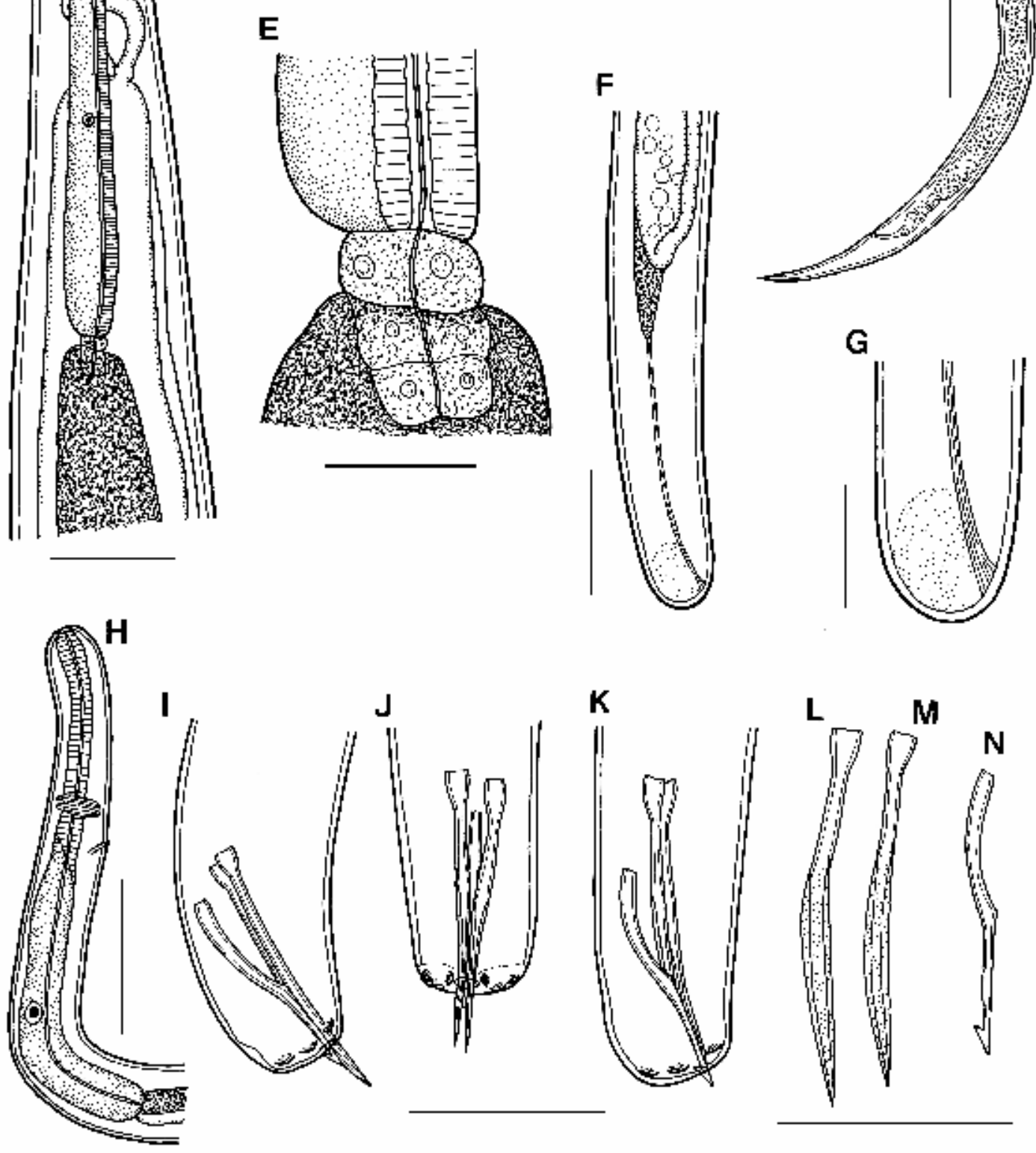

K
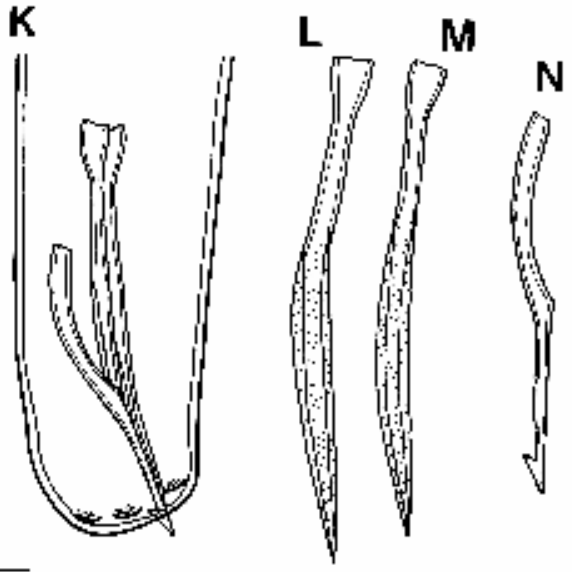

Fig. 1. Philometra carolinensis sp. n. A- $\mathbf{G}$ - gravid female (A - anterior end of body, lateral view; $\mathbf{B}, \mathbf{C}$ - cephalic end, lateral and apical views; D - larva from uterus; $\mathbf{E}$ - region of oesophago-intestinal junction; $\mathbf{F}$ - posterior part of body, lateral view; $\mathbf{G}$ caudal end, lateral view); $\mathbf{H}-\mathbf{N}$ - male (H - anterior end of body, lateral view; I, J - caudal end, lateral and ventral views; $\mathbf{K}$ caudal end of another specimen, lateral view; $\mathbf{L}, \mathbf{M}$ - spicule in two different specimens, lateral views; $\mathbf{N}$ - gubernaculum, lateral view). Scale bars: $A, F=200 \mu \mathrm{m} ; \mathrm{B}, \mathrm{D}, \mathrm{G}, \mathrm{H}=100 \mu \mathrm{m} ; \mathrm{C}=20 \mu \mathrm{m} ; \mathrm{E}, \mathrm{I}-\mathrm{N}=50 \mu \mathrm{m}$. 

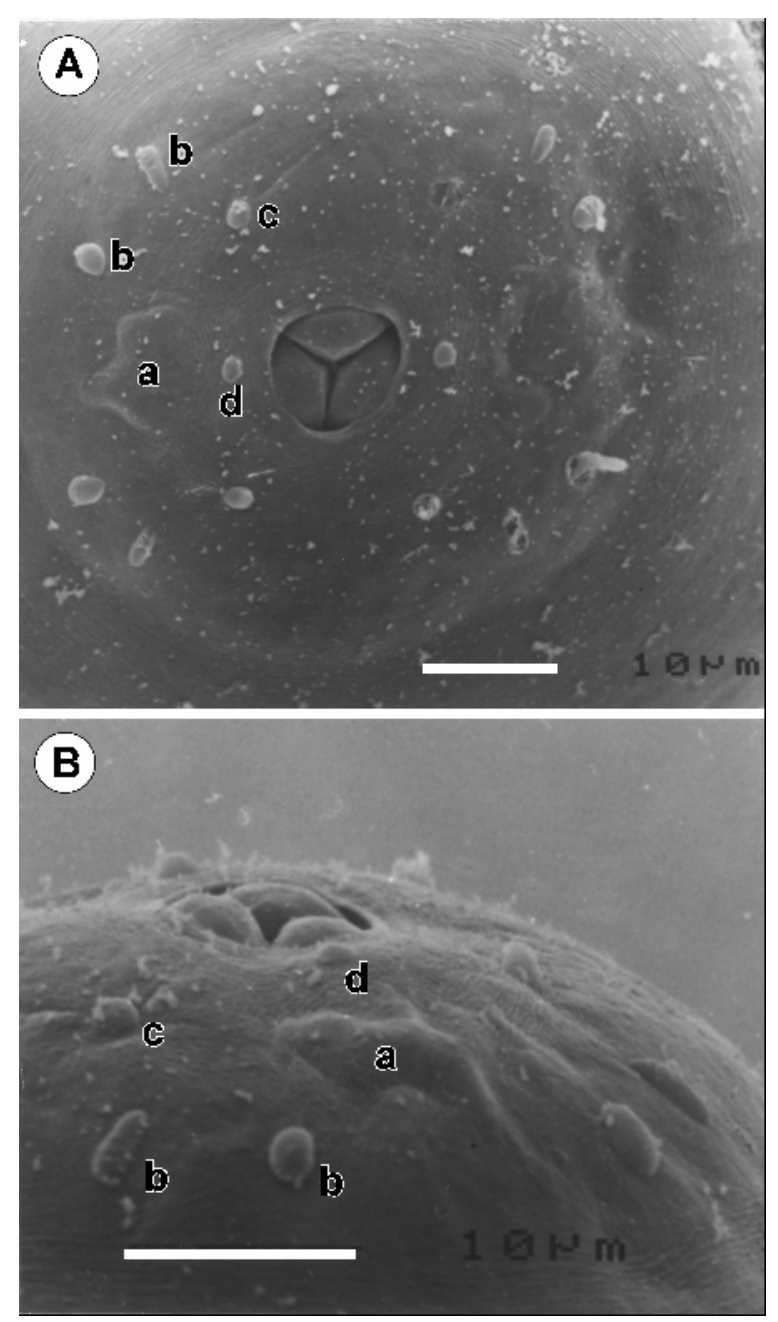

Fig. 2. Philometra carolinensis sp. n., scanning electron micrographs of gravid female. A, B - cephalic end, apical and sublateral views. Abbreviations: $\mathrm{a}$ - amphid; $\mathrm{b}$ - submedian cephalic papilla of outer circle; $\mathrm{c}$ - submedian cephalic papilla of inner circle; $\mathrm{d}$ - lateral cephalic papilla of inner circle. Scale bars: $A, B=10 \mu \mathrm{m}$.

two pairs of postanal very flat, hardly visible caudal papillae. Spicules well sclerotized, equally long, with distinctly expanded proximal and sharply pointed distal tips; length of spicules 81-87 (84), representing 5 (5)\% of body length; anterior parts of spicules light-coloured, posterior more heavily sclerotized parts brownish. Gubernaculum narrow, 57-69 (63) long, with approximately its proximal half somewhat dorsally bent; distal tip of gubernaculum pointed, with distinct reflect dorsal barb. Length ratio of gubernaculum and spicules $1: 1.23-1.42$ (1:1.33).

Gravid and subgravid female (5 gravid specimens; measurements of 1 subgravid female in parentheses): Body of fixed specimens conspicuously narrow, whitish to yellowish, with distinct dark-brown coloured intestine visible through cuticle, with rounded ends. Posterior part of body narrower than anterior part; maximum width in region posterior to oesophagus. Body length 115.09-156.74 (108.80) mm, maximum width 558-653 (530); maximum width/length ratio of body 1:184-263 (1:205). Cuticle smooth. Width of cephalic end 177-204 (177). Cephalic papillae very small, indistinct when viewed laterally. Oral aperture large, oval, surrounded by 4 pairs of small submedian cephalic papillae of outer circle and 6 single papillae (2 lateral and 4 submedian) of inner circle (Fig. 2A, B). Pair of small lateral amphids present. Anterior ends of three oesophageal sectors protruding out of mouth as small oesophageal teeth (Fig. 2B). Oesophagus narrow, swollen near mouth to form bulb 63-66 (66) long and 57-66 (60) wide, not separated from posterior cylindrical part of oesophagus. Overall length of oesophagus 1.10-1.25 (1.14) mm, representing $0.8-0.9$ (1.0)\% of body length; maximum width of its cylindrical part 95 (95). Dorsal oesophageal gland well developed, extending anteriorly to level of nerve ring and posteriorly to small ventriculus; gland provided with large cell nucleus located in about its middle, 762-830 (680) from anterior extremity. Ventriculus 30 long, 72 wide in specimen measuring 132 $\mathrm{mm}$ in length. Nerve ring 204-286 from anterior end of body. Posterior end of intestine atrophied, forming ligament attached ventrally to body wall, not far anterior to posterior extremity. Posterior end of body rounded, 109-141 (112) wide, without caudal projections; small round darker tissue appears to be present in caudal end. Vulva and vagina absent. Ovaries of medium length, reflected, situated near anterior and posterior ends of body. Uterus occupies most of body, being filled with eggs, developing embryos and first-stage larvae with rounded anterior end and sharply pointed tail. Larvae from uterus 399-462 long, maximum width 15-21; length of their oesophagus $129-150$ (32-34\% of body length), that of tail 63-75 (14-19\% of body length).

Nongravid female: Body length of 3 specimens collected in July ranged from 90 to $95 \mathrm{~mm}$.

$\mathrm{T}$ y p e h o s t: Spotted seatrout, Cynoscion nebulosus $(\mathrm{Cu}-$ vier) (Sciaenidae, Perciformes) (range total length: 278$560 \mathrm{~mm}$ ).

Site of infection: Ovary (both males and females).

T y p e 1 o c a 1 i t y: West Atlantic Ocean, off South Carolina (Charleston), USA $\left(32^{\circ} 30^{\prime} \mathrm{N}, 80^{\circ} 35^{\prime} \mathrm{W}\right.$ to $33^{\circ} 18^{\prime} \mathrm{N}$, $79^{\circ} 12^{\prime} \mathrm{W}$ ) (dates of collection: females from April through July 2005 and males in November 2005).

P r e v a l e n c e : 39\% (81 fish infected / 207 fish examined); in ten sity: $1-14$.

E t y m o log y: The specific name of this nematode relates to South Carolina where this parasite was recorded.

Deposition of type specimens: Holotype (male) USNPC 97479, allotype (female) USNPC 97480, paratype male USNPC 97481 and paratype females USNPC 97482 in the U.S. National Parasite Collection, Beltsville, Maryland. Paratypes (males and females) in the Institute of Parasitology, ASCR, České Budějovice (Cat. No. N-855). 
Comments: Only females of this nematode were collected from April to July 2005. The general morphology and measurements of these specimens were, more or less, in accordance with those of Philometra lateolabracis (Yamaguti, 1935) (see the key to Philometra spp. parasitic in the gonads of marine fishes by Moravec and Genc 2004) and, therefore, they were first considered to belong to this species. However, in November 2005, also four males were found and their morphology proved to be very different from that of $P$. lateolabracis, as it was described by Crisp and Klein (1973), Merella et al. (2004), Moravec and Genc (2004) and Moravec and Justine (2005).

Philometra lateolabracis, a parasite of fish gonads, has been reported from more than 20 fish species of the perciform families Carangidae, Centropomidae, Glaucosomidae, Haemulidae, Lutjanidae, Mullidae, Percichthyidae, Polynemidae, Serranidae, Sciaenidae and Sparidae, but also Paralichthyidae and Psettotidae (both Pleuronectiformes), mainly from tropical and subtropical regions of the Pacific, Indian and Atlantic Oceans (Moravec 2006). However, because the male of $P$. lateolabracis has not yet been described from the type host [Lateolabrax japonicus (Cuvier) (Percichthyidae)] in Japan and the majority of records are based solely on females, it cannot be excluded that, in fact, $P$. lateolabracis includes more than one species (Moravec et al. 1998). The males of $P$. lateolabracis have been described from Haemulon plumieri (Lacépède) (Haemulidae) off the Atlantic coast of Brazil (Crisp and Klein 1973), Mycteroperca rubra (Bloch) and Epinephelus marginatus (Lowe) (both Serranidae) in the Mediterranean Sea (Merella et al. 2004, Moravec and Genc 2004) and from Epinephelus cyanopodus (Richardson) and E. fasciatus (Forsskål) (Serranidae) off New Caledonia (Moravec and Justine 2005).

The males of $P$. carolinensis differ from those of $P$. lateolabracis in having markedly shorter spicules (8187 vs. $114-213 \mu \mathrm{m})$, which are of a different shape and structure (distal parts of spicules expanded and heavily sclerotized vs. not expanded), their gubernaculum is provided with a distinct reflect dorsal barb on the distal end (vs. dorsal barb absent), and the length ratio of the gubernaculum and spicules is $1: 1.23-1.42$ (vs. $1: 1.81-$ 2.38). The gravid female of $P$. carolinensis possesses small oesophageal teeth (Fig. 2B), which are absent from the gravid female of $P$. lateolabracis (see Moravec 2006). Distinction of $P$. carolinensis from other congeneric species parasitizing the gonads of marine fishes is evident from the key provided by Moravec and Genc (2004)

Philometra carolinensis is the 15th known species of Philometra parasitizing the gonads of marine fishes (see Moravec and Genc 2004). Parasites of this group may be highly pathogenic, causing serious damage to fish ovaries, and may thus affect fish reproduction (Rama- chandran 1975, Sakaguchi et al. 1987, Moravec et al. 2003).

Philometra cynoscionis sp. $\mathrm{n}$.

Figs. 3, 4

Gravid and subgravid female (4 gravid specimens; measurements of holotype in parentheses; measurements of 1 additional subgravid female in square brackets): Body of fixed specimens brownish, with distinctly visible brown intestine. Body cylindrical, 19.98-33.25 (28.81) [13.22] $\mathrm{mm}$ long, somewhat tapering at both ends; posterior part somewhat narrower than anterior part; maximum width of body 707-1,047 (966) [408] near its middle; width of cephalic end 150-190 (190) [122]. Ratio of maximum body width and overall length of body 1:28-32 (1:30) [1:32]. Cuticle almost smooth, with very fine transverse striation. Cephalic end blunt, provided with marked cephalic papillae and pair of small lateral amphids. Oral aperture relatively small, oval, surrounded by four pairs of large oval papillae arranged in outer circle (2 papillae subdorsal, 2 subventral, 2 dorsolateral and 2 ventrolateral; dorso- and ventrolateral papillae somewhat smaller) (Figs. 3D, 4A, D) and six (2 lateral and 4 submedian) single papillae of inner circle (Fig. 4C, F). Bottom of mouth formed by flat surfaces of three oesophageal sectors. Anterior end of oesophagus swollen to form well-developed bulb 90 135 (120) [75] long and 114-165 (150) [105] wide. Long posterior portion of oesophagus almost cylindrical, provided with well-developed, wide oesophageal gland extending anteriorly just posterior to level of nerve ring; oesophageal gland containing large cell nucleus located somewhat posterior to its middle, at 843$1,333(1,170)$ [816] from anterior extremity. Overall length of oesophagus including anterior bulb 1.22-1.78 (1.65) [1.17] mm, representing 5-6 (6) [9]\% of body length; maximum width of cylindrical part including oesophageal gland 190-204 (190) [82]. Small ventriculus, 21-41 (41) [27] long and 42-95 (82) [54] wide, present, opening into intestine through valve. Nerve ring 231-272 (272) [204] from anterior end of body. Intestine relatively narrow, its posterior end atrophied, forming short translucent ligament attached ventrally to body wall near posterior extremity. Posterior end of body somewhat narrowed, rounded, without any caudal projections. Ovaries short, narrow, reflected. Uterus occupying major part of body, extending anteriorly nearly to level of nerve ring, posteriorly to end of intestinal ligament. Uterus of gravid specimens filled with numerous larvae 324-450 (not measured in holotype) long and 12 wide $(\mathrm{n}=5)$; length of their oesophagus and sharply pointed tail 105-135 (27-36\% of body length) and 66105 (20-28\% of body length), respectively.

Male: Unknown.

T y p e ho s t: Spotted seatrout, Cynoscion nebulosus $(\mathrm{Cu}-$ vier) (Sciaenidae, Perciformes) (range total length: 278$560 \mathrm{~mm}$ ). 

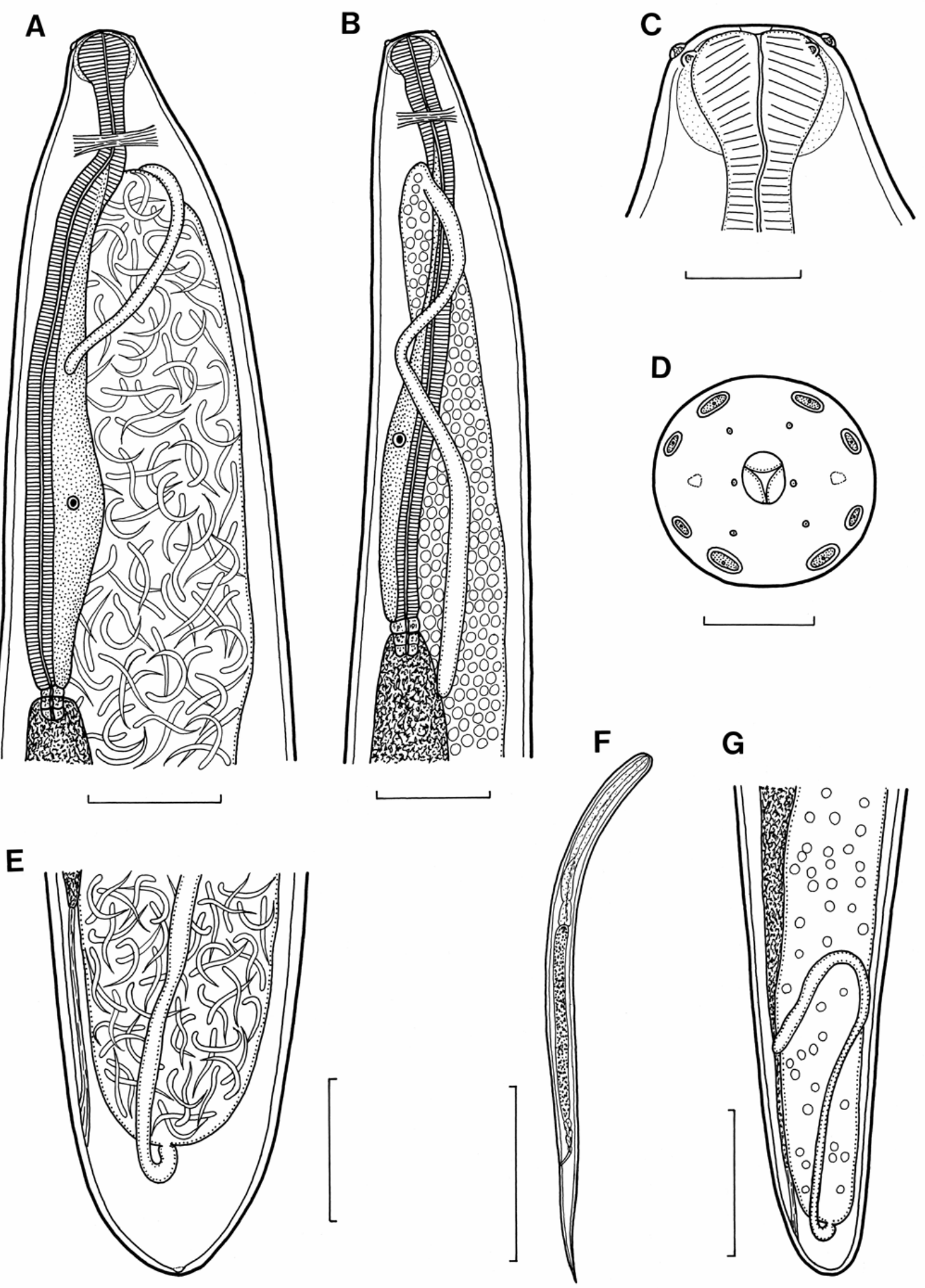

Fig. 3. Philometra cynoscionis sp. n., female. A, B - anterior part of body of gravid and subgravid specimens, respectively, lateral views; C, D - cephalic end of gravid specimen, lateral and apical views; $\mathbf{E}$ - posterior end of gravid specimen, lateral view; $\mathbf{F}$ - larva from uterus; $\mathbf{G}$ - posterior end of subgravid specimen, lateral view. Scale bars: $\mathrm{A}=300 \mu \mathrm{m} ; \mathrm{B}=200 \mu \mathrm{m} ; \mathrm{C}, \mathrm{E}, \mathrm{F}=100$ $\mu \mathrm{m} ; \mathrm{D}=50 \mu \mathrm{m} ; \mathrm{G}=500 \mu \mathrm{m}$.

S it e of infection: Embedded in tissue lateral to the ascending process of the premaxilla and also in tissue be- tween the maxilla and anterior region of the skull, usually found more frequently medial to the distal maxilla. 
Ty p e 1 o c a 1 it y: West Atlantic Ocean, estuarine South Carolina $\left(32^{\circ} 30^{\prime} \mathrm{N}, 80^{\circ} 35^{\prime} \mathrm{W}\right.$ to $33^{\circ} 18^{\prime} \mathrm{N}, 79^{\circ} 12^{\prime} \mathrm{W}$ ) (dates of collection: April through July 2005).

P r e v a 1 e n c e : $49 \%$ (51 fish infected / 104 fish examined); intensity: $1-9$.

E t y m o lo g y: The specific name of this nematode is derived from the generic name of its fish host.

De position of types: Holotype USNPC 97483 and paratypes USNPC 97484 in the U.S. National Parasite Collection, Beltsville, Maryland. Some paratypes in the helminthological collection of the Institute of Parasitology, ASCR, České Budějovice (Cat. No. N-856).

Comments: The genus Philometra Costa, 1845 includes a large number of species parasitic in the abdominal cavity or in various body tissues of freshwater, brackish-water and marine fishes. Since minute males of most species remain unknown, the present identification of species is principally based on the female morphology (Rasheed 1963, Ivashkin et al. 1971, Moravec 2004). However, the morphology of females is rather uniform, not providing many features for distinguishing the species, which makes the identification difficult. In addition to morphological characters, data on the site of localisation of gravid females in the host's body are important for the identification of philometrids (Moravec and Rohde 1992, Moravec 2004).

Moravec and Ali (2005) have recently listed 12 species of Philometra the gravid females of which are parasitic in fish subcutaneous tissues, fins and musculature: P. bagri (Khalil, 1965), P. beninensis Obiekezie, 1986, $P$. kohnae Moravec et Rohde, 1992, P. lomi Moravec et Rohde, 1992, P. oreoleucisci Moravec et Ergens, 1970, $P$. pinnicola (Yamaguti, 1935), P. plotosi Moravec et Nagasawa, 1989, P. rischta Skryabin, 1923, P. sebastodis Yamaguti, 1941, P. strongylurae Moravec et Ali, 2005, P. sydneyi Rasheed, 1963, and P. tylosuri Moravec et Ali, 2005.

Of them, P. bagri, P. oreoleucisci and P. rischta are parasites of freshwater fishes in Africa or Palaearctic Eurasia and can easily be differentiated from $P$. $c y$ noscionis by the structure of the cephalic end (presence of four conspicuous cephalic lobes) and two welldeveloped, large caudal projections. Of the remaining species, all parasites of marine fishes, $P$. pinnicola, $P$. sebastodis and $P$. tylosuri possess very small or indistinct cephalic papillae, the cephalic end of $P$. lomi bears four papilla-like lobes, and $P$. sydneyi has three conspicuously large, anteriorly protruding oesophageal teeth, by which these species distinctly differ from $P$. cynoscionis.

Eight large cephalic papillae of an outer circle are present only in P. beninensis, $P$. kohnae, $P$. plotosi and $P$. strongylurae. However, the gravid female of $P$. plotosi from the pectoral fins of Sebastes joyneri Günther (Sebastidae) off Japan is only 5-6 mm long (vs. 20-33 mm), whereas that of $P$. kohnae from the subcutaneous tissue of Tylosurus gavialoides (Castelnau)
(Belonidae) off Australia is $34-76 \mathrm{~mm}$ long; both species also differ from $P$. cynoscionis in the absence of the inner circle of cephalic papillae. The body length $(20$ $35 \mathrm{~mm}$ ) of gravid female in $P$. beninensis from the subcutaneous tissue of head, fins and the inner surface of operculum of Polydactylus quadrifilis (Cuvier) (Polydactylidae) off Nigeria and in P. strongylurae (15-20 $\mathrm{mm}$ ) from the subcutaneous tissues, musculature and gills of Strongylura spp. (Belonidae) off Iraq is similar to that in $P$. cynoscionis. However, in contrast to $P$. cynoscionis, the external cephalic papillae of the former have a different distribution and all are equal in size (see Obiekezie and Anders 1991), whereas the latter has no cephalic papillae of the inner circle. The maximum body width/length ratio of $P$. strongylurae is 1:11-19 (vs. 1:28-32) and the length of its oesophagus forms 9$11 \%$ (vs. 5-6\%) of the overall body length.

Eight large external cephalic papillae are also present in the gravid females of $P$. opsalichthydis Yamaguti, 1935 and $P$. parasiluri Yamaguti, 1935 from the abdominal cavity of freshwater Cyprinidae (Opsariichthys, Zacco) and the orbit of Silurus asotus Linnaeus (Siluridae), respectively, in Japan and in P. salgadoi VidalMartínez, Aguirre-Macedo et Moravec, 1995 from the ocular cavity of Epinephelus morio (Valenciennes) (Serranidae) in the Gulf of Mexico (Yamaguti 1935, Vidal-Martínez et al. 1995, Moravec et al. 2001). However, all three species differ distinctly from $P$. $c y$ noscionis in having a pair of large papilla-like caudal projections in the gravid female, in addition to some other differences.

Fishes of the perciform family Sciaenidae seem to be rather frequent hosts of philometrid nematodes, but mostly those parasitic in the fish gonads, reported as Philometra lateolabracis (Yamaguti, 1935) or P. sciaenae Yamaguti, 1941, and now also P. carolinensis. Otherwise, only Philometra sp. has been reported from the oculo-orbit of the freshwater drum Aplodinotus grunniens Rafinesque in North America and juvenile females of Philometra beninensis were recorded in the flesh of Pseudolithus senegalensis (Valenciennes) off the Atlantic coast of Nigeria (see Moravec 2006). Consequently, $P$. cynoscionis is the fourth determined adult Philometra species known to parasitize sciaenid fishes.

Recently, without giving details, Blaylock and Overstreet (2003) reported adult females of a philometrid designated as Margolisianum sp. from the tissues of the mouth of Cynoscion nebulosus in the southern USA (probably in the Gulf of Mexico). It is highly probable that their nematodes were, in fact, conspecific with Philometra cynoscionis. The systematic status of Margolisianum Blaylock et Overstreet, 1999 and its type species M. bulbosum Blaylock et Overstreet, 1999 will be soon dealt with in our next paper treating philometrids from the southern flounder Paralichthys lethostigma Jordan et Gilbert. 


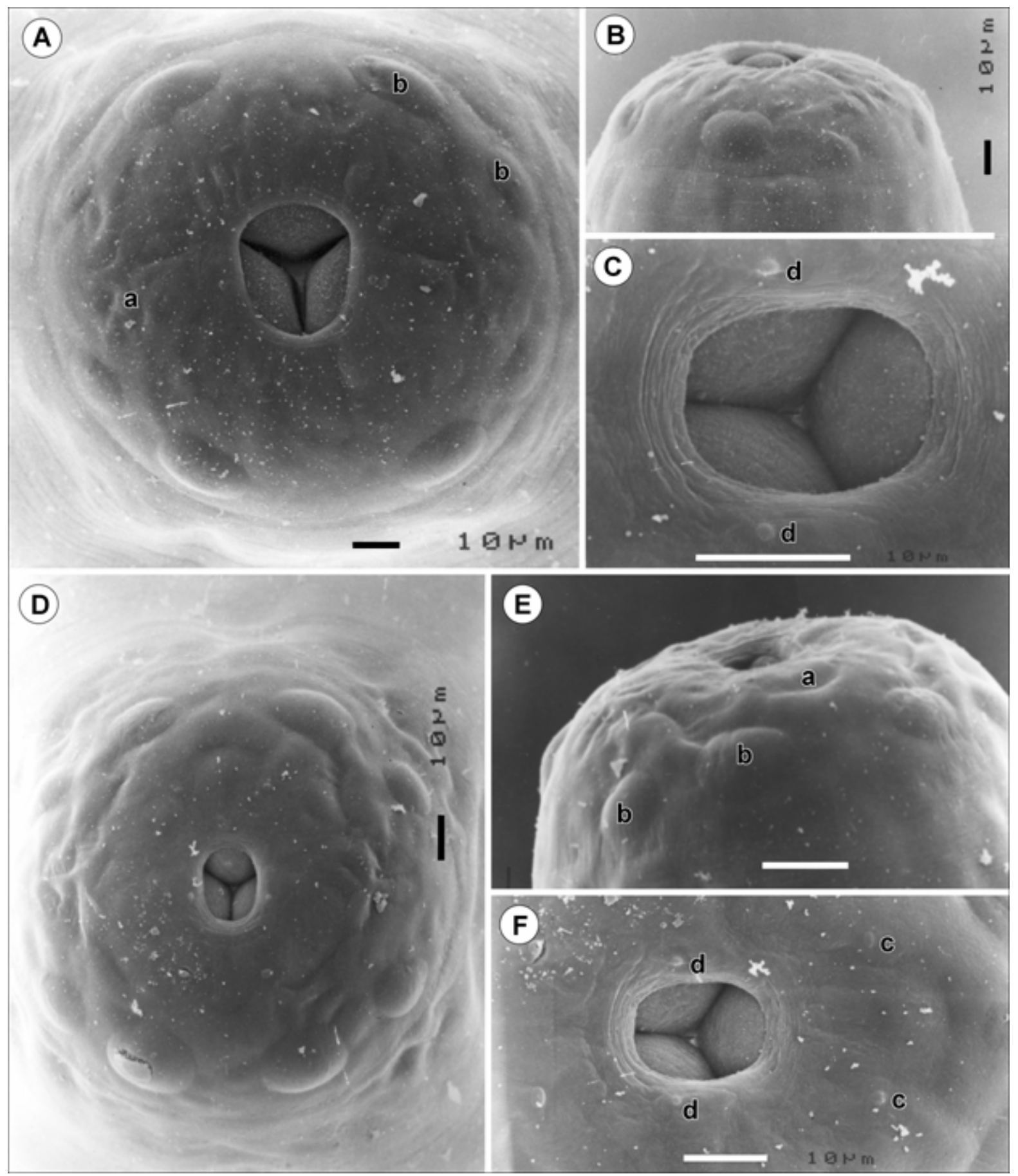

Fig. 4. Philometra cynoscionis sp. n., scanning electron micrographs of gravid female. A, B - cephalic end, apical and sublateral views; $\mathbf{C}$ - region of oral opening with distinct lateral cephalic papillae of inner circle; $\mathbf{D}, \mathbf{E}$ - cephalic end of another specimen, apical and sublateral views; $\mathbf{F}$ - region of mouth with distinct lateral and submedian papillae of inner circle. Abbreviations: a amphid; b - cephalic papilla of outer circle; $c$ - submedian cephalic papilla of inner circle; $d$ - lateral cephalic papilla of inner circle. Scale bars: A-F $=10 \mu \mathrm{m}$.

Acknowledgements. The authors acknowledge Dr. Robert Dillon (College of Charleston) and Ms. Gina Perez (SC-DNR) for their keen eyes and precious involvement in this work. Thanks are also due to the staff of the Laboratory of Electron Microscopy, Institute of Parasitology, ASCR, in České Budějovice for their technical assistance, and to Mrs. Irena Husák- ová, a technician of the same Institute, for her help with illustrations. This study was partly supported by the grant no. 524/06/0170 from the Grant Agency of the Czech Republic, Research Centre "Ichthyoparasitology" (LC522), and by the research project of the Institute of Parasitology, ASCR (no. Z60220518). 


\section{REFERENCES}

BLAYLOCK R.B., OVERSTREET R.M. 2003: Diseases and parasites of the spotted trout. In: Bortone S.A. (Ed.), Biology of the Spotted Seatrout. CRC Press, Boca Raton, pp. 197-225.

CRISP D.J., KLEIN V.L.M. 1973: Contribution to the knowledge of Philometra lateolabracis Yamaguti, 1935 (Nematoda, Filarioidea). Mem. Inst. Oswaldo Cruz 71: 481-483.

FROESE R., PAULY D. (Eds.) 2005: FishBase. World Wide Web electronic publication. www.fishbase.org, version $12 / 2005$.

IVASHKIN V.M., SOBOLEV A.A., KHROMOVA L.A. 1971: [Camallanata of Animals and Man and the Diseases Caused by Them. Osnovy nematodologii 22.] Nauka, Moscow, 388 pp. (In Russian.)

MERELLA P., REÑONES O., GARIPPA G. 2004. Finding of one male Philometra lateolabracis (Nematoda: Philometridae) parasite on the dusky grouper Epinephelus marginatus (Osteichthyes: Serranidae) in the western Mediterranean. Parassitologia 46 (Suppl. 1): 158.

MORAVEC F. 2004: Some aspects of the taxonomy and biology of dracunculoid nematodes parasitic in fishes: a review. Folia Parasitol. 51: 1-13.

MORAVEC F. 2006: Dracunculoid and Anguillicoloid Nematodes Parasitic in Vertebrates. Academia, Prague. (In press.)

MORAVEC F., ALI A.H. 2005: Two new species of Philometra (Nematoda: Philometridae) from needlefishes (Belonidae) in Iraq, with a key to Philometra spp. parasitic in the host's subcutaneous tissue, fins and musculature. Folia Parasitol. 52: 267-273.

MORAVEC F., GENC E. 2004: Redescription of three Philometra spp. (Nematoda, Philometridae) from the gonads of marine perciform fishes of Iskenderun Bay (North-East Mediterranean), Turkey. Acta Parasitol. 49: 31-40.

MORAVEC F., GLAMUZINA B., MARINO G., MERELLA P., DI CAVE D. 2003: Occurrence of Philometra lateolabracis (Nematoda: Philometridae) in the gonads of marine perciform fishes in the Mediterranean region. Dis. Aquat. Org. 53: 267-269.

MORAVEC F., JUSTINE J.-L. 2005: Two species of Philometra (Nematoda, Philometridae) from serranid fishes off New Caledonia. Acta Parasitol. 50: 323-331.
MORAVEC F., NAGASAWA K., OGAWA K. 1998: Observations on five species of philometrid nematodes from marine fishes in Japan. Syst. Parasitol. 40: 67-80.

MORAVEC F., ROHDE K. 1992: Three species of nematodes of the superfamily Dracunculoidea from Australian fishes. Acta Soc. Zool. Bohemoslov. 56: 187-195.

MORAVEC F., VIDAL-MARTÍNEZ V.M., AGUIRREMACEDO M.L., GONZÁLEZ-SOLÍS D. 2001: First description of the male and redescription of the female of Philometra salgadoi Vidal-Martínez et al., 1995 (Nematoda: Philometridae) from the ocular cavity of the marine fish Epinephelus morio in Mexico. Parasitol. Res. 87: 526-529.

NELSON J.S., CROSSMAN E.J., ESPINOSA-PÉREZ H., FINDLEY L.T., GILBERT C.R., LEA R.N., WILLIAMS J.D. 2004: Common and Scientific Names of Fishes from the United States, Canada, and Mexico. Sixth Edition. American Fisheries Society, Spec. Publ. 29, Bethesda, Maryland, $386 \mathrm{pp}$.

OBIEKEZIE A.I., ANDERS K. 1991: Scanning electron microscope studies on Philometra (Ranjhinema) beninensis Obiekezie, 1986 (Nematoda: Philometridae). Folia Parasitol. 38: 371-374.

RAMACHANDRAN P. 1975: Philometra cephalus sp. n. infecting the gonads of the striped mullet, Mugil cephalus L. from the Arabian coast of Kerala, India, with a note on its pathology. Zool. Anz. 194: 140-144.

RASHEED S. 1963: A revision of the genus Philometra Costa, 1845. J. Helminthol. 37: 89-130.

SAKAGUCHI S., YAMAGATA Y., SAKO H. 1987: Reidentification of Philometra parasitic on the Red Sea bream. Bull. Nat. Res. Inst. Aquacult. 12: 69-72. (In Japanese, English summary.)

VIDAL-MARTÍNEZ V.M., AGUIRRE-MACEDO M.L., MORAVEC F. 1995: Philometra (Ranjhinema) salgadoi n. sp. (Nematoda: Philometridae) from the ocular cavity of the red grouper Epinephelus morio (Pisces: Serranidae) from the Yucatan Peninsula, Mexico. J. Parasitol. 81: 763766.

YAMAGUTI S. 1935: Studies on the helminth fauna of Japan. Part 9. Nematodes of fishes, 1. Jpn. J. Zool. 6: 337-386. 